\title{
MISUNDERSTANDING OF THE INDONESIAN HUMAN RIGHTS ACTIVISTS ON THE APPLICATION OF THE DEATH PENALTY
}

\author{
Tajul Arifin * \\ Faculty of Shari'ah and Law, Sunan Gunung Djati State Islamic University of Bandung \\ Email: tajularifin64@uinsgd.ac.id
}

\begin{abstract}
This research mainly uses statistical data published by the United Nations Office on Drugs and Crime (UNDDC) in April 2014 to support the hypothesis of this research that "Human Rights Activists in Indonesia as in other countries have failed in comprehending the wisdom (hikmah) of the application of Capital Punishment". This study found that: (1) the hypothesis of this research was strongly supported by the data; (2) the application of Syari ah Criminal Law in Saudi Arabia has been an unchallenged proof for the wisdom (hikmah) behind the application of Capital Punishment by keeping the level of murder crime to a low rate which sharply contrast to many countries which apply positive laws which are based on a social contract between the ruler and the ruled, such as in The United States and Mexico; and (3) In upholding the true justice in Islamic Criminal Law, punishment can only be awarded to the criminals in a society where the Islamic ideal of social justice has been achieved.
\end{abstract}

\begin{abstract}
Abstrak
Penelitian ini menggunakan data statistik yang diterbitkan oleh United Nations Office on Drugs and Crime (UNDDC) pada bulan April 2014 untuk mendukung hipotesis dari penelitian ini bahwa "Aktivis HAM di Indonesia seperti di negara-negara lain telah gagal dalam memahami hikmah dari penerapan hukuman mati". Studi ini menemukan bahwa: (1) hipotesis penelitian ini sangat didukung oleh data; (2) penerapan Hukum Pidana Syari ah di Arab Saudi telah menjadi bukti tak terbantahkan untuk menunjukkan hikmah di balik penerapan hukuman mati dengan menjaga tingkat kejahatan pembunuhan pada tingkat yang sangat rendah yang sangat berlawanan dengan yang terjadi di banyak negara yang menerapkan hukum positif yang didasarkan pada kontrak sosial antara penguasa dan rakyat, seperti di Amerika Serikat dan Meksiko; dan (3) dalam menegakkan keadilan sejati dalam Hukum Pidana Islam, hukuman hanya dapat diberikan kepada penjahat dalam masyarakat di mana keadilan sosial yang ideal menurut Islam telah dicapai.
\end{abstract}

Kata kunci:

Hukuman mati, aktivis hak asasi manusia, Hukum Pidana Islam, pembunuhan

\section{A. Introduction}

The Indonesia Human Rights activists coalition, that is, "Civil Coalition of Anti-Death Penalty" that consists of Imparsial, Contrast, YLBHI, Elsam, HRWG, LBH Pers, LBH Masyarakat (Legal Aid Society), PBHI, and others have asked the government of Indonesia to discuss the issue of the death penalty on Monday, 16 May 2016. ${ }^{1}$ They have offered some reasons in asking the

*Tajul Arifin is a Professor of the Science of the Prophet Traditions and Doctor of Sociology at the Faculty of Shari'ah and Law, Sunan Gunung Djati State Islamic University of Bandung. Correspondence related to the content of this article should be addresed to: tajularifin64@uinsgd.ac.id, or 08179220810 also for both WA and LINE 
government to abolish the death penalty from the Indonesia law system and cancel the execution of death penalty. Among the reasons they offer are the law enforcement system in Indonesia is still not perfect, so will be very vulnerable to potential corruption cases and the engineering mob justice is increasingly widespread. In addition, in Indonesia the execution is done in the justice system is still dilapidated, it becomes very difficult to be corrected if one day it turns out executions was applied to the wrong people; while the death penalty when it is executed cannot be corrected. ${ }^{2}$ Besides those reasons, according to the writer even the most influential reasons - that the Indonesia Human Rights activists as their colleagues in other countries in the world have failed in understanding the spirit of the application of Capital Punishment as ruled by the Islamic Law. This is the main problem faced by modern societies as a consequence of weak of their belief in the teaching of Allah Almighty and His Laws. In regulating all aspects of their life, including in creating the harmony in their societies, they have left the Law of Allah for their new regulations which they have considered much better than the Law of Allah. Human Rights activists misunderstanding on Capital Punishment has great impact on the abolition of the Capital Punishment in many countries since part of their activity is to negotiate their government in abolishing Capital Punishment from their law system, or at least not to execute Capital Punishment.

Data released by Amnesty International related to the use of capital punishment can be divided into the four categories set out as follow. As of June 2016, of the 195

1 http://www.beritadunia.net/berita-dunia/ indonesia/menolak-hukuman-mati,-sekelompok-Ismanti-hukuman-mati-geruduk-istana-presiden. Accessed 5 June 2016

${ }^{2}$ Ibid. independent states that are UN members or have UN observer status: (1) 105 have abolished it for all crimes; (2) 6 have abolished it, but retain it for exceptional or special circumstances (such as crimes committed in wartime); (3) 47 retain it, but have not used it for at least 10 years or are under a moratorium; and (4) 37 retain it in both law and practice. Recent complete abolition of capital punishment are: Gabon (2010), Latvia (2012), Benin (2012), Mongolia (2012), Madagascar (2012), Fiji (2015), Suriname (2015), Congo (2015), Nauru (2016), and Guinea (2016). ${ }^{3}$

In the opposite, the number of murders has gone in the opposite direction. In the USA for example, during the temporary suspension on capital punishment from 1972-1976, researchers gathered murder statistics across the country. In 1960, there were 56 executions in the USA and 9,140 murders. By 1964, when there were only 15 executions, the number of murders had risen to 9,250. In 1969, there were no executions and 14,590 murders, and 1975, after six more years without executions, 20,510 murders occurred rising to 23,040 in 1980 after only two executions since 1976. In summary, between 1965 and 1980, the number of annual murders in the United States skyrocketed from 9,960 to 23,040 , a 131 percent increase. The murder rate homicides per 100,000 persons - doubled from 5.1 to 10.2 . So the number of murders

3 "Final Declaration 6th World Congress Against the Death Penalty, Oslo, 23 June 2016". Accessed through http://congres.abolition.fr/wpcontent/uploads/2016/06/Final-Declaration-of-the-6thWorld-Congress- Against-the-Death-Penalty.pdf, 20 July 2016; "Death Penalty Execution at 25 Years High, Amnesty Reports". Accessed through http://www.euronews.com/2016/07/20/death-penaltyexecutions-at-a-25-year-high-amnesty-reports 20 July 2016; and "Crime in the United States" https://en.wikipedia.org/ wiki/ Capital_ punishment_by_country. Accessed 20 July 2016. 
grew as the number of executions shrank. ${ }^{4}$ The most recent figures available was released by Centers for Disease Control and Prevention's in 2011that showed there were around 16,238 murders per year in the United States; this averages out to around 44 murders per day. ${ }^{5}$

In the last four decades, sociologists have paid greater attention to the study of the effects of the law and its potential to produce social order, rather than the study of criminals or the strategies of the police. In addition, in the last five years, Human Rights Activists in Indonesia had strongly rejected the application of Capital Punishment as has been regulated in Islamic Criminal Law. Therefore, the questions need to answer seem to be, (1) do the statistical data on murder strongly support the hypothesis that "Human Rights Activists in Indonesia as in other countries have failed in comprehending the wisdom (hikmah) of the application of Capital Punishment"; (2) do the statistical data on murder support the existence of wisdom (hikmah) behind the application of Capital Punishment; and (3) does Capital Punishment in Islamic Criminal Law system applied arbitrarily in any societies without considering the level of economic welfare and security of society?

This research report begins by summarizing a sociological theoretical framework on crime-punishment relationships. The following section presents Capital Punishment in Islamic Criminal Law. The final section examines the deterrent effects of the application of capital punishment on crime in many countries, through the

${ }^{4}$ Naci Mocan, The Deterrent Effect of Capital Punishment (2006), Internet Resources, accessed through http://www.wesleylowe.com, 10 June 2016. https://www.reference.com/governmentpolitics/many-people-murdered-day-united-states4ce42C 41 82d89232. Accessed 10 June 2016. presentation and discussion of some statistical data and provides a conclusion.

\section{A. The Relationship between Crime and Punishment}

In analyzing the social impact of the application of the capital punishment in many countries, especially on the crime rate, it is worthwhile to summarize the theoretical framework which explains the relationship between crime and punishment. Considering the "severity" of capital punishment, this section will summarize the previous works which examine the relationships between the sanction level and the crime rate.

The results of social scientists researches in this area can be divided into two groups. The first is the group who argue that punishment has a deterrent effect on crime. The deterrence theory suggests that "the severity and certainty of punishments are additive factors". In other words, when punishments are severe and administered with certainty, maximum deterrence results. In contrast, when punishments are slight and uncertain, deterrence will be minimal. The theorists which support this hypothesis are Erlich; ${ }^{6}$ Brier and Fienberg (1980), ${ }^{7}$ Pratt (1990), ${ }^{8}$ and Naci Mocan (2006). ${ }^{9}$ In other words, they argue that punishment in general creates a greater balance of happiness vs. unhappiness. From this perspective, then, capital punishment is justified if it (1) prevents the criminal from repeating his crime; or (2) deters crime by discouraging would-be offenders.

${ }^{6}$ Isaac Erlich, "The Deterrent Effect of Capital Punishment: A Question of Life and Death," American Economic Review, 1979, 65: 397-417.

${ }^{7}$ S.S. Brier and S.E. Fienberg, "Recent Economic Modeling of Crime and Punishment: Support for the Deterrence Hypothesis?," Evaluation Review, 1980, 4: 147-91.

8 John Pratt, "Crime, Time, Youth and Punishment," Contemporary Crises, 1990, 14: 219-42.

${ }^{9}$ Naci Mocan, Loc. Cit. 
Conversely, the second group argues that an increase in the severity of the penalty has no impact on criminal behavior at equilibrium. The defenders of this hypothesis argue that there is no evidence to support the deterrence hypothesis. According to this group, the defenders of the deterrence theory have some methodological problems in their studies. In contrast to the deterrence theorists, these theorists argue that the death penalty should be abolished even if criminals deserve death for what they did. The punishment theorists who support this hypothesis, among others, are Reiman (1985), ${ }^{10}$ Davis and Reiman (1990), ${ }^{11}$ Roger Hood (2002), ${ }^{12}$ and James Fieser (2015). ${ }^{13}$ In brief, these theorists support the softening of sanctions and are against the severity of punishment like in Islamic Criminal Law. This opinion then held and popularized by the Indonesia Human Rights Activists and even they strongly opposed the application of death penalty in Indonesia. They have strong networks with other Human Rights Activist from many countries especially with those from the United States and European countries in abolishing the death penalty.

\section{B. Islam and Capital Punishment}

No religion is more complete than Islam. Islam is a very complete religion. “... Nothing have We omitted from the Book, and they (all) shall be gathered to their Lord

10 Jeffrey Reiman, "Justice, Civilization, and the Death Penalty: Answering van den Haag," Philosophy and Public Affairs, 1985, 14: 115-48.

${ }^{11}$ M. Davis and J. Reiman, "The Death Penalty, Civilization, and Inhumaneness," Social Theory and Practice, 1990, 16: 245-59.

${ }^{12}$ Roger Hood, The Death Penalty: A World-wide Perspective (Oxford: Clarendon Press, 2002), third edition.

${ }^{13}$ James Fieser, Capital Punishment, from Moral Issues that Divided Us and Applied Ethics: A Source Book. Accessed through

https://www.utm.edu/staff/jfieser/class/16o/7-cappun.htm, 10 June 2016. in the end" (Al-An'am [Cattle], 6: 38). ${ }^{14}$ It is not just a set ritual for God, but to control all aspects of human life, including in the areas of law ranging from the smallest to the greatest; ranging from civil to criminal law, and even ethics. With regard to the death penalty, Islam has been set up with a very firm and clear in the Qur'an as well as AlSunnah. The Holy Qur'an has clearly and repeatedly mentioned about capital punishment. In the verse 32 of Al-Maidah (The Table), Allah Almighty says:

"...If anyone kills a person - unless it be for murder or for spreading mischief in the land - it would be as if he killed all people. And if anyone saves a life, it would be as if he saved the life of all people" (Al-Maidah [The Table], 5: 32). ${ }^{15}$

According to Islam and most other world faiths, life is sacred. But how can one hold life sacred, yet still support capital punishment? The Qur'an answers:

"...Take not life, which God has made sacred, except by way of justice and law. Thus does He command you, so that you may learn wisdom" (Al-An'am [Cattle], 6: 151). ${ }^{16}$

According to Islam, the key point is that one may take life only "by way of justice and law." In Islam, therefore, the death penalty can be applied by a court as punishment for the most serious of crimes. Ultimately, one's eternal punishment is in God's hands, but there is a place for punishment in this life as well. The spirit of the Islamic penal code is to save lives, promote justice, and prevent corruption and tyranny. Islamic philosophy holds that a harsh punishment serves as a deterrent to

${ }^{14}$ Abdullah Yusuf Ali, The Meaning of The Holy Qur'an, (Maryland, U.S.A.: Amana Cooperation, 2014), p. 348.

\footnotetext{
${ }^{15}$ Ibid., p. 292.

${ }^{16}$ Ibid., p. 389
} 
serious crimes that harm individual victims, or threaten to destabilize the foundation of society. According to Islamic law (in the first verse quoted above), the following two crimes can be punishable by death: (1) Intentional murder and (2) Fasad fil-ardh ("spreading mischief in the land").

\section{Intentional Murder}

The Holy Qur'an regulates the death penalty for murder, although forgiveness and compassion are strongly encouraged. The murder victim's family is given a choice to either insist on the death penalty, or to pardon the perpetrator and accept monetary compensation for their loss, “...

But if any remission is made by the brother of the slain, then grant any reasonable demand, and compensate him with handsome gratitude. This is a concession and a mercy from your Lord..." (Al-Baqarah, 2: $178) .^{17}$

\section{Fasad fi al-ardh}

The second crime for which capital punishment can be applied is a bit more open to interpretation. "Spreading mischief in the land" can mean many different things, but is generally interpreted to mean those crimes that affect the community as a whole, and destabilize the society. Crimes that have fallen under this description have included:
a. Treason / Apostacy (when one leaves the faith and joins the enemy in fighting against the Muslim community);
b. Terrorism;
c. Land, sea, or air piracy;
d. Rape;
e. Adultery; and
f. Homosexual behavior. ${ }^{18}$

\footnotetext{
${ }^{17}$ Ibid., p. 73

${ }^{18}$ For further discussion about this topic consult Abdul Qadir Audah, Al-Tarikh al-Jina'iy al-Islami Muqaranan bi al-Qanun al-Wahi'y, II, (Beirut: Muassasah al-Risalah, 1994); Sayyid Sabiq, Fiqh al-Sunnah, (Beirut: Dar al-Fikr, 1980); and Wahbah Zuhaily, Al-Figh al-Islami wa Adillatuhu, (Damaskus: Dar Al-Fiqr, 1989).
}

The actual methods of capital punishment vary from place to place. In some Muslim countries, methods have included beheading, hanging, stoning, and firing squad. Executions are held publicly, to serve as warnings to would-be criminals. It is important to note that there is no place for vigilantism in Islam -- one must be properly convicted in an Islamic court of law before the punishment can be meted out. The severity of the punishment requires that very strict evidence standards must be met before a conviction is found. The court also has flexibility to order less than the ultimate punishment (for example, imposing fines or prison sentences), on a case-by-case basis.

In the case of murder, the Holy Quran definitely encourages capital punishment (AlBaqarah [The Cow], 2: 179) ${ }^{19}$ to protect the life of individual. "... The free for the free, the slave for the slave, and the female for the female..." (2: 178). ${ }^{20}$ Due to human meanness and injustice, many people such as the Indonesia Human Rights activists cannot even imagine what this Quranic verse says. They refuse to accept the clear injunctions that strict equivalence must be observed ---if a woman kills a man, or a man kills a woman, or a slave kills a free person, or a free person kills a slave--- capital punishment cannot be applied. The Quran prefers that the murderer compensate the victim's family. Killing the murderer does not bring the victim back, nor does the family of the victim benefit from executing the murderer. The compensation, however, must be sufficient to be a deterrent for others. In Islam (Submission), to some extent, the victim and/or the victim's family have a right of choice for all crimes; they decide what the punishment shall be under the supervision of a person who knows the Quran. If a thief

\footnotetext{
${ }^{19}$ Abdullah Yusuf Ali, Loc. Cit.

${ }^{20}$ Ibid.
} 
steals a thousand dollars from you, and they put him in prison, what do you get? If the thief has a wife and children, what is their crime? Why should they be deprived of their father? The Quran solves this problem, as well as the problems associated with the criminal justice systems prevalent in today's world.

According to the Quranic criminal justice, the thief who is convicted of stealing a thousand dollars from you must work for you until you are fully paid for the thousand dollars you lost, plus any other damage and inconvenience the theft may have caused you. At the same time, the thief's innocent wife and children are not deprived of their man, and the expensive prison system is eliminated. Imprisonment as popularized by modern law system and supported by Human Rights activists is a cruel and inhumane punishment that has proven useless to all concerned. In contrast to common belief, the thief's hand shall not be cut off. Thank God for His mercy and His mathematical miracle in the Quran, we know now that the thief's hand is to be marked. Marking the hand of the thief is stated in the Chapter of Al-Maidah (The Table), 5: 38: "As to the thief, male or female cut off his or her hands: a retribution for their deed and exemplary punishment from Allah, and Allah is exalted in power, full of wisdom". ${ }^{21}$ The chapter and verse numbers add up to $5+38=$ 43. The other place in the Quran where "the hand is cut" is found in 12: 31, "... when they saw him, they did extol him, and (in their amazement) cut their hands ...".22 This is where we see the women who admired Joseph so much they "cut" their hands. Obviously, they did not sever their hands; no one can do that. The chapter and verse numbers add up to $12+31=43$, the same total

\footnotetext{
${ }^{21}$ Ibid., p. 295

${ }^{22}$ Ibid., p. 635
}

as in 5:38. This gives mathematical confirmation that the Quranic law calls for marking the hand of the thief, not severing it. Additional mathematical confirmation is provided: 19 verses after 12: 31, we see the "cutting of the hand" again. Punishment in Islam (Submission) is based on equivalence and social pressure (Al-Baqarah [The Cow], 2: 178, Al-Maidah [The Table], 5: 38, Al-Nur [Light], 24: 2). The blasphemy called "Hadith \& Sunna" has instituted stoning to death as the punishment for married adulterers. This is not God's law. As stated in 24: 2, the punishment for adultery is whipping in public; a hundred symbolic lashes. As pointed out above, the basic punishment is social pressure and scandalizing the criminal. In fact, whipping in public caould achieve this goal.

\section{Social Impact of the Application of Capital Punishment: A critique to the Indonesia Human Rights Activists}

In this part, the writer would like to show some data from some Moslem countries as well as from other countries. Muslim countries in this paper are defined as the countries in which most of the populations are Muslims such as Inonesia. Since only some Muslim countries which apply Syariah law have availability source of data, in examining the social impact of the application of Syariah law more specifically capital punishment, this paper will mainly refer to the case of the Kingdom of Saudi Arabia and United States of America for comparison.

In Indonesia, as in many other Muslim countries, the aplication of non-Syari'ah law has a long historical background. Even though Indonesia has the biggest number of Muslim citizens in the world, ${ }^{23}$ this country

${ }^{23}$ According to the result of 2010 Population Census, 207.175.708 population of Indonesia are Moslem 
does not apply Syariah except Nangroe Aceh Darussalam (NAD). This is primarily due to the Western colonialism. Another factor in the case of Indonesia is the political domination by Western educated thinkers (nationalists) who have sought to secularize this country through their political authorities since the Soekarno to Joko Widodo regimes.

In general, Muslim Middle East countries have had similar experiences. Since the Napoleonic invasion of Egypt (17981801), the countries of the Middle East, with exception of parts of Saudi Arabia, were directly or indirectly subjected to the force of European Imperialism. ${ }^{24}$ Unavoidably, in the beginning of their awakening, they adopted a Western model of progress and development, and even borrowed Western law. Until the 1970s the countries of the Muslim Middle East seemed to be embarked on a program of modernization in the Western style that would inevitably lead to ever greater secularization. ${ }^{25}$

Then, in the late 1970s, the process of islamization began in the Middle East countries. Two countries that have most seriously and systematically pursued islamization are Iran and Pakistan. In both countries it is clear that the official version of

(87.18\%) from the total population of 237.641 .326 (Biro Pusat Statistik, "Penduduk menurut Wilayah dan Agama yang Dianut", Sensus Penduduk Tahun 2010, (Jakarta: Biro Pusat Statistik). If we look at to the percentage, Moslem population in Indonesia is actually decreasing since has been already known that in 2000 the percentage of Moslem population was $88.2 \%$.

${ }^{24}$ See R.R. Andersen, et al, Politics and Change in the Middle East: Source of Conflict and Accommodation (New Jersey: Prentice Hall, 1990); Samsul Munir Amin, Sejarah Peradaban Islam, Cet. II (Jakarta: Amzah, 2010); and Syamsul Bakri, Peta Sejarah Peradaban Islam, (Yogyakarta: Fajar Media Press, 2011).

${ }^{25}$ See A.E. Mayer, "Law and Religion in the Muslim Middle East," The American Journal of Comparative Law, 1987, 35: 127-84; Samsul Munir Amin, Sejarah Peradaban Islam, Cet. II (Jakarta: Amzah, 2010); and Syamsul Bakri, Peta Sejarah Peradaban Islam, (Yogyakarta: Fajar Media Press, 2011). islamization pursued after the 1978-79 Iranian Revolution and President Zia's presence to power in 1977, presuppose that Islam is an ideology. ${ }^{26}$ Saudi Arabia is a leading country in the Middle East which has applied Syariah. In addition to the absence of factors which constrain to the process of Islamization in other Middle East Muslim countries, that being colonialism, Saudi Arabia has another conducive factor, that is, the presence of Ulama (Muslim scholars). Unlike other Muslim countries in this region, in Saudi Arabia, Ulama occupies prominent positions in the state's political elite. Furthermore, Saudi Arabia was applying Islamic Law since the Prophet Muhammad (pbuh) era. Therefore, the Ulama's effective role in Saudi Arabia was very conducive in maintaining the continuity of the application of Syariah law in this Kingdom. ${ }^{27}$ In this regard, A.E. Mayer ${ }^{28}$ says that "Saudi Arabia has never adopted a constitution out of respect for the classical Islamic precept that all laws are contained in the Syariah sources".

Syari ah is a theocratic system. It sets out Allah's commands to humanity. The Syari'ah was divine revelation, as determined by the text of the Qur'an, supplemented by the sayings and deeds of the Prophet preserved in tradition (Sunna), the

${ }^{26}$ Consult Badri Yatim, Sejarah Peradaban Islam Dirasah Islamiyah II. Cet. IV, (Jakarta: PT Raja Grafindo Persada, 1996); Rubya Mehdi, "The Offence of Rape in the Islamic Law of Pakistan," International Journal of the Sociology of Law, 1990, 18: 19-29; Don Peretz, The Middle East Today (New York: Praeger, 1988); Samsul Munir Amin, Sejarah Peradaban Islam, Cet. II (Jakarta: Amzah, 2010); and Syamsul Bakri, Peta Sejarah Peradaban Islam, (Yogyakarta: Fajar Media Press, 2011).

${ }^{27}$ A good discussion about this, see Aharon Layish, "Ulama and Politics in Saudi Arabia," in Metin Heper and Raphael Israeli (eds.), Islam and $P$; litics in the Modern Middle East (London: Croom Helm, 1984), pp.: 29-63; Fadil SJ., Pasang Surut Peradaban Islam dalam Lintasan Sejarah. Cet. I, (Malang: UIN Malang Press, 2008); and N.J. Coulson, A History of Islamic Law (Edinburgh: The University Press, 1964).

${ }^{28}$ A.E. Mayer, Op. Cit., p. 135. 
consensus of scholars (ijma), and analogical reasoning (qiyas). ${ }^{29}$ The Syari ah, for its part, was bounded on one side by administrative direction, the directions power of Caliphs (siyasi) manifested itself in secular ordinances (the qanun, or the nizam and the marsum of the Hanbali school). The Syariah judge himself might occasionally award a discretionary punishment (ta'zir) instead of the foreordained sanctions of the sacred law (hadd, pl. hudood). On the other side, custom (urf) circumscribed the holy rules. ${ }^{30}$

By referring to Saudi Arabia, this part will look at the impact of the application of Syariah on social life, especially on homocide. Syari ah criminal code is severe in manner. In fact, the severity of its punishment has a great deterrent effect on crime. The application of Syariah in Saudi Arabia, for example, was able to maintain the low crime rates in this country as shown in Table 1.

Table 1

Murder Rate in the Kingdom of Saudi Arabia Selected Years (Data Availability) $)^{31}$

${ }^{29}$ See Al-Jurjani, al-Ta'rifât, (Beirut: Dar Al- Fikr, n.d.), p. 167; R.R.,Andersen, et al, Politics and Change in the Middle East: Source of Conflict and Accommodation (New Jersey: Prentice Hall, 1990); Ibn al-Manzhur, Lisân al-'Arab, Vol. I, (Bairut: Dar al-Ahya', n.d.), p.175; Yusuf Qardhawi, Membumikan Syariat Islam, (Bandung: Mizan Pustaka, 2003); Mahmud Syaltut, Al-Islam, 'Aqidah wal Syari'ah, (Kairo: Dar al-Qalam, 1996), p. 12; Abdul Wahhab Khallaf, Ilmu Ushul Figh, (Semarang: Dina Utama Semarang (Toha Putera Group), 1994); AlGhazali, Al-Mustasfa min 'Ilmu al-Ushul, (Mesir: Maktabah al-Jumdiyah, 1971); Muhammad Abu Zahrah, Ushul Fiqih, (Jakarta: PT. Pustaka Firdaus, 1995); Safi Hasan Abu Thalib, Tathbiq al-Syari'ah al-Islamiyah fi alBilad al-Arabiyah, (Kairo; Dar al-Nahdah al-Arabiyah, 1990); A.Djazuli dan I. Nurol Aen, Ushul Fiqh, (Bandung: Gilang Aditya Press, 1996); and Zakariya al-Biri, Mashadir al-Ahkam al-Islamiyah, (Kairo; Dar al-ittihad alArabi Littiba'ah, 1975).

${ }^{30}$ Joseph Schact, An Introduction to Islamic Law (New York: Clarendom Press, 1964), p. 54. See also Abdul Qadir Audah, Al-Tasyri'al-Jinaiy al-Islamiy, (Beirut: Daar al-Kitab al-Arabiy, n.d.).

${ }^{31}$ Adapted from James Sheptycki, Ali Wardak, and James Hardie-Bick, Transnational and Comparative Criminology, (Routledge Cavendish, 2005), p. 95.

\begin{tabular}{|c|c|}
\hline Year & $\begin{array}{c}\text { Homicide Rate per year per } \\
100,000 \text { Population }\end{array}$ \\
\hline 1988 & 0.11 \\
2002 & 0.60 \\
2006 & 0.10 \\
2013 & 0.80 \\
\hline
\end{tabular}

Table 1 reveals very low official murder rates in the Kingdom of Saudi Arabia since 1988-2013. The population included in the table includes more than one-third foreign ex-patriots who are generally attributed with a higher crime rates than native Saudis. If we look at the average number of murders, under one a year in every 100,000 population is certainly very low. The low rate of homicide in Saudi Arabia will be more clearly when compared to the rate in some countries in the world which apply State Law as shown in Table 2.

Table 2

Number of Murders in the Kingdom of Saudi Arabia Compared to other Countries in the World Which Apply State Law Various Year (2013-2014) 32

\begin{tabular}{|l|l|r|l|}
\hline Countries & $\begin{array}{c}\text { Murder } \\
\text { Rate Per } \\
100,000 \\
\text { Population }\end{array}$ & Count & $\begin{array}{c}\text { Year } \\
\text { Listed }\end{array}$ \\
\hline SAUDI & 0.8 & 234 & 2013 \\
ARABIA & 33.0 & 17.805 & 2014 \\
South & 27.9 & 13.343 & 2014 \\
Africa & 15.7 & 19.669 & 2013 \\
Colombia & 3.9 & 12.253 & 2013 \\
Mexico & & & \\
United & & & \\
States & & & \\
\hline
\end{tabular}

To strengthen the truth of the deterrent effects of the application of Syari ah law on crime rates in Saudi Arabia,

${ }^{32}$ United Nations Office on Drugs and Crime (UNDDC), Global Study on Homocide, April 2014. 
Table 2 compares the crime rates of Saudi Arabia with four countries which apply state law and strongly against the application of capital punishment, more importantly the United States. Table 2 shows that the murder rate in Saudi Arabia is the lowest among the five countries. These data, clearly indicate the deterrent effects of the application Syari ah on crime in Saudi Arabia. Tabel 2 shows that murder rates in the United States is almost 5 times higher than in Saudi Arabia. Moreover, the murder rate in the South Africa is more than 41 times higher than in Saudi Arabia.

To strengthen the theory of the deterrent effects of the severity of Syariah criminal law on crime, the writer also presents the data of crime rate of Saudi Arabia where Syariah law is applied compared to region and world rates. Table 3 shows this comparison.

It is known from Table 3 that the world murder rate is almost eight times the rate in Saudi Arabia. Compared to murder rate in Asia where Saudi Arabia is part of the region, the data show that murder rate in Asia is almost four times the ratein Saudi Arabia. Asia is clearly has the lowest murder rate among the region in the world. This is, according to the writer, to some extent, part of the constribution of some countries ehich still apply Capital Punishment. Again, it is clear that Table 3 indicates the deterrent effects of the severity punishment of Syariah criminal code on murder rate in the Kingdom of Saudi Arabia. This finding strongly supports the previous study which argued that punishment has deterrent effects on crime. This theory now is challenged by many Human Rights Activists in Indonesia as in many other countries. Under the name of human rights to life they strongly oppose the application of Capital
Punishment without knowing deeply the wisdom (al-hikmah) behind the Law of God.

Table 3

Murder Rate in the Kingdom of Saudi Arabia Compared to Regions and World Rates (per 100, 000), 2013 33

\begin{tabular}{|l|l|r|}
\hline $\begin{array}{c}\text { Country, Region, } \\
\text { and World } \\
\text { Compared }\end{array}$ & $\begin{array}{c}\text { Murder } \\
\text { Rate }\end{array}$ & \multicolumn{1}{c|}{ Count } \\
\hline Saudi Arabia & 0.8 & 234 \\
World & 6.2 & 437.000 \\
Americas & 16.3 & 157.000 \\
Africa & 12.5 & 135.000 \\
Europe & 3.0 & 22.000 \\
Oceania & 3.0 & 1.100 \\
Asia & 2.9 & 122.000 \\
\hline
\end{tabular}

This research paper has approached the deterrent effect of punishment in Islamic Criminal Law, especially Capital Punishment for murder. It has been suggested that this study supports the deterrence theory of law. In most literature, crime has generally been considered as either the consequence of existing social conditions or the outcome of a traditional calculation by a predator which chooses crime as a utility-maximizing career. As a result, these approaches propose either an improvement in social conditions or an increase in penalties or punishments as a means to reduce criminal activity. Though the severity of punishment in Islamic Criminal Law which is applied in Saudi Arabia shows a deterrence affect on murder rate, I would not necessarily argue that punishment is the best or only way to control crime. But rather argue that punishment is only part of large, more complicated factors which cause the low crime rate. The more severe the punishment, 
as outlined in Islamic Law, the lower crime rate will be.

It is common that the severity of punishment in Islamic Criminal Law is often misinterpreted by many human right activists, especially among the West. To understand correctly the perception of severity of punishment in Islamic Criminal Law we must examine in its SupernaturalSocial frame of the principle of Qishash (the law of equality). Such a frame, assuring the will of God, totally relieves any concern among Muslim believers concerning the severity of punishment, particularly since it ensures justice to all offenders. Unlike in the Western contemporary judicial system in which discrimination a common feature of this system, the Islamic judicial system places all offenders subject to the same treatment. Richard Quenney illustrates how the contemporary Western judicial system works:

Obviously judicial decisions are not made uniformly. Decisions are made according to a host of extra-legal factors, including the age of the offender, his race, and social class. Perhaps the most obvious example of judicial discretion occurs in the handling of cases of persons from minority groups. Negroes, in comparison to whites, are convicted with lesser evidence and sentenced to more severe punishment. ${ }^{34}$

Conversely, Syariah law is applied equally to all citizens. This assertion is suggested in the Qur'anic verse, Al-Hujurat, 49: 13: "... Verify the most honoured of you, in the sight of Allah, is the most righteous of you...". ${ }^{35}$ Also the Prophet says: "The Arab is not more worthy than the Parsian, and the

${ }^{34}$ Richard Quinney, The Social Reality of Crime, (Boston: Little, Brown, 1970), p. 142.

${ }^{35}$ Abdullah Yusuf Ali, Op. Cit., p. 1593. red is not more deserving than the black, except in godliness." ${ }^{136}$ The second relates to a saying by the Prophet in which he stated that "if his own daughter, Fatima, committed theft, her kinship ties to him would not save her legal punishment". ${ }^{37}$

In the Islamic Judicial system, the equal treatment of offenders is applied in both theory and practice. In 1981 for example, we still remember that Saudi Arabia's Islamic Judicial Court executed a Royal princess of the Kingdom with her lover who were convicted of adultery. The case was later made into the widely known movie feature, "Death of a Princess."

As a system, Islam gives an equal treatment not only to people from different race, class and color, but also to people from different religion. There is no reason for nonMuslim to fear of living under Islamic State (Syari'ah law). The non-Muslim who lives in an Islamic State and enjoys all their human rights which are enshrined in the Syari'ah are called Ahla Dhimmah or Dhimmis, the convicted people. The Dhimmis living in an Islamic State are guaranteed the protection of their life, property and their honor exactly like that of a Muslim. The rights given to a Dhimmis are of an irrevocable nature. It becomes every Muslim's religious duty to protect life, property and honour of a nonMuslim since it forms a part and parcel of his faith..$^{38}$

The Islamic state would not be fanatic and intolerant of minorities since Islam is the

36 Al-Bukhari, Shahih Al-Bukhari, trans. Muhammad Mukhsin Khan (Pakistan: Kazi Publication, 2010), Vol. VIII, p 39.

${ }^{37}$ Ibid., pp. 512-13.

${ }^{38}$ See Abdul Qadir Audah, Al-Tasyri'al-Jinaiy alIslamiy, (Beirut: Daar al-Kitab al-Arabiy, n.d.); Joseph Schact, An Introduction to Islamic Law (New York: Clarendom Press, 1964); Abdul-Aziz Said, "Precept and Practice of Human Rights in Islam," Universal Human Rights, 1979, 1: 63-79; and A. Rahman I. Doi, NonMuslims Under Syari'ah (Islamic Law) (Pakistan: Kazi Publication, 1981). 
most tolerant of religions. For example, Umar Ibn al-Khaththab, the second caliph, had asked on his deathbed that his successor should take care to protect the Dhimmis. The Qur'an itself called for religious tolerant: "You have your religion; I have mine (AlKafirun [The Disbelievers]), 109: 6)." 39 In the Chapter of Al-Baqarah (The Cow) verse 193, Allah says: “... but if they cease, Let there be no hostility except to those who practice oppression". ${ }^{40}$ Then, in the Chapter of AlTaubah (Repentance) verse 6 Allah says: "If one amongst the Pagans ask thee for asylum, grant it to him, so that he may hear the word of Allah. And then escort him to where he can be secure. That is because they are men without knowledge"41.

Besides that, another thing which needs to be considered is the historical background in which Islam has been developed. Islam has descended in Saudi Arabia where its old tribes practiced causal killing of raids and counter-raids over trivial matters. In this situation, Qishash (the law of equality) is culturally accepted as a plausible method to prevent greater retribution against the offender or his family and tribe. In fact, history has proved the magical power of Syari ah in deterring the continuity of causal killing in trivial matters in the Arabian tribal community. Is this prevention method not applicable in the contemporary modern world in which the machine gun and any other tools to kill other persons are within easy access and the criminal's mode operation is more sophisticated? Consider modern terrorism, or how often kidnapping occurs in our society. We still remember the incident of 14 July 2016 where a truck was used to kill many people (more than 30 people according to the information

\footnotetext{
${ }^{39}$ Abdullah Yusuf Ali, Op. Cit., p. 2022.

${ }^{40}$ Ibid., p. 80.

${ }^{41}$ lbid., p. 498.
}

released by the government) who were celebrate Bastille Day in the city of Nice, South France. ${ }^{42}$

In addition, in terms of the Supernatural-Individual frame, which is determined by the personal conscience of believers capital punishment is not perceived as a means to frighten the "believers" but rather as a necessary by-product of justice mechanism ordained to deter a climate of lawlessness and social disorganization. In the Chapter of Al-Baqarah (The Cow) verses 17879 Allah says:

178. O ye who believe! the law of equality (qishash) ${ }^{43}$ is prescribed to you in cases of murder: the free for the free, the slave for the slave, the woman for the woman. But if any remission is made by the brother of the slain, then grant any reasonable demand, and compensate him with handsome gratitude, this is a concession and a Mercy from your Lord. After this whoever exceeds the limits shall be in grave penalty.

179. In the Law of Equality there is (saving of) Life to you, o ye men of understanding; that ye may restrain yourselves. ${ }^{44}$

Moreover, it is important to identify that capital punishment seems to be an act

http://www.bbc.com/indonesia/dunia/2016/07/160714_d unia_nice_teror. Accessed 20 July 2016.

${ }_{43}$ Qishaash is taking the same retaliation. Qishaash was not done if the killing gets forgiveness of heirs who were killed is to pay blood money (compensation) were reasonable. Blood money payment is requested by the well, for example by not urging the killing, and killing let pay well, for example not delay it. When the heirs of the victim after the Lord explains these laws, which is not the killer killed, or kill the killer after receiving blood money, then taken qishaash against him in the world and in the Hereafter he got a painful chastisement (Soenarjo, dkk., Al-Qur'an dan Terjemahnya, (Jakarta: Departemen Agama RI., 2013), p. 43.

${ }^{44}$ Abdullah Yusuf Ali, Op. Cit., p. 78. 
of mercy to those with a strong tendency to commit crime, because when compared with long-term prison sentences which in time lose their effectiveness, the execution of "bodily penalty" (flogging and cutting the hand) offer clear advantages. It allows the criminal to resume his work almost immediately, to support himself and his family, and to serve as an act of penance and remission. More important, the execution will prevent the individual from committing the same crime in the future, serving as a stern warning to others.

\section{Conclusion}

Based on the discussion, this paper concludes the followings. Firstly, Human Rights activists in Indonesia as in other countries have failed in comprehending the wisdom (hikmah) behind the application of Capital Punishment as clearly outlined in Islamic Criminal Law. Second, the application of Syari ah Criminal Law in Saudi Arabia has been able to keep the level of murder crime to a low rate. In contrast, in many countries which apply positive laws which are based on a social contract between the ruler and the ruled, such as in The United States, South Africa, Colombia, and Mexico, the murder crime rate is remain high. Third, punishment in Islamic Criminal Law can only be awarded to the criminals in a society where the Islamic ideal of social justice has been achieved.

\section{BIBLIOGRAPHY}

Abu Thalib, Safi Hasan (1990), Tathbiq alSyari'ah al-Islamiyah fi al-Bilad alArabiyah, (Kairo; Dar al-Nahdah alArabiyah).

Abu Zahrah, Muhammad (1995), Ushul Fiqih, (Jakarta: PT. Pustaka Firdaus).
Ali, Abdullah Yusuf (2014), The Meaning of The Holy Qur'an (Maryland, U.S.A.: Amana Cooperation).

Amin, Samsul Munir (2010), Sejarah Peradaban Islam, Cet. II (Jakarta: Amzah).

Amnesty International (2006), Facts and Figures on the Death Penalty, Internet Resources, accessed through http://www.amnesty.org, Accessed 10 June 2016.

Andersen, R.R., et al (1990), Politics and Change in the Middle East: Source of Conflict and Accommodation (New Jersey: Prentice Hall).

Audah, Abdul Qadir (N.d.), Al-Tasyri'al-Jinaiy al-Islamiy, (Beirut: Daar al-Kitab alArabiy).

Audah, Abdul Qadir (1994), Al-Tarikh al-Jina'iy al-Islami Muqaranan bi al-Qanun alWahi'y, II, (Beirut: Muassasah alRisalah).

Avio, K and Clark, C.S. (1976), Property Crime in Canada: An Econometric Study (Toronto: University of Toronto Press).

Bakri, Syamsul (2011), Peta Sejarah Peradaban Islam, (Yogyakarta: Fajar Media Press).

BBC (2016), “Insiden Truk Menabrak Kerumunan Orang di Nice". http://www.

bbc.com/indonesia/dunia/2016/07/16071 4_dunia_nice_teror. Accessed 20 July 2016.

Becker, Gary (1968), "Crime and Punishment: An Economic Approach," Journal of Political Economy, 76: 169-217.

Biro Pusat Statistik (2010), "Penduduk menurut Wilayah dan Agama yang Dianut", Sensus Penduduk Tahun 2010, (Jakarta: Biro Pusat Statistik).

Birri, Zakariya al (1975), Mashadir al-Ahkam alIslamiyah, (Kairo; Dar al-ittihad al-Arabi Littiba'ah). 
Brier, S.S. and Fienberg, S.E. (1980), "Recent Economic Modeling of Crime and Punishment: Support for the Deterrence Hypothesis?," Evaluation Review, 4: 147-91.

Bukhari, Al (2010), Shahih Al-Bukhari, Vol. VIII, trans. Muhammad Mukhsin Khan (Pakistan: Kazi Publication).

Cloninger, Dale (1975), "The Deterrent Effect of Law Enforcement: An Evaluation of Recent Findings and Some New Evidence," American Journal of Economic and Sociology, 34: 323-35.

Coulson, N.J. (1964), A History of Islamic Law (Edinburgh: The University Press).

Davis, M. and Reiman, J. (1990), "The Death Penalty, Civilization, and Inhumaneness," Social Theory and Practice, 16: 245-59.

Djazuli, A. dan I. Nurol Aen, Ushul Fiqh, (Bandung: Gilang Aditya Press, 1996).

Doi, A. Rahman I. (1981), Non-Muslims Under Syariah (Islamic Law) (Pakistan: Kazi Publication).

Erlich, Isaac (1979), "The Deterrent Effect of Capital Punishment: A Question of Life and Death," American Economic Review, 65: 397-417.

Fieser, James (2015), Capital Punishment, from Moral Issues that Divided Us and Applied Ethics: A Source Book. Accessed through

https://www.utm.edu/staff/jfieser/class / 160/7-cap-pun.htm, 10 June 2016.

Gallagher, James J. (1989), The Role of Values and Facts in Policy Development for Infants and Toddlers with Disabilities and Their Families, (Carolina: University of North Carolina). Ghazali, al (1971), Al-Mustasfa min 'Ilmu alUshul, (Mesir: Maktabah al-Jumdiyah).

Hood, Roger (2002), The Death Penalty: A World-wide Perspective (Oxford: Clarendon Press), third edition. http://www.beritadunia.net/beritadunia/indonesia/menolak-hukumanmati,-sekelompok-Ism-anti-hukumanmati-geruduk-istana-presiden.

Accessed 5 June 2016.

Johnson, L. and Weigert, A.J. (1980), "Frames in Confession: The Social Construction of Sexual Sin," Journal for the Study of Religion, 19: 368-81.

Jurjani, al, Al- Ta'rifat, (N.d.), (Beirut: Dar AlFikr).

Khallaf, Abdul Wahhab (1994), Ilmu Ushul Figh, (Semarang: Dina Utama Semarang [Toha Putera Group]).

Layish, Aharon (1984), "Ulama and Politics in Saudi Arabia," in Metin Heper and Raphael Israeli (eds.), Islam and Politics in the Modern Middle East (London: Croom Helm), pp.: 29-63.

Manzhur, Ibnu (N.d.), Lisan al-Arab, Jilid V, (Bairut: Dar al-Ahya').

Mayer, A.E. (1987), "Law and Religion in the Muslim Middle East," The American Journal of Comparative Law, 35: 127-84.

Mehdi, Rubya (1990), "The Offence of Rape in the Islamic Law of Pakistan," International Journal of the Sociology of Law, 18: 19-29.

Mocan, Naci (2006), The Deterrent Effect of Capital Punishment, Internet Resources, accessed through http://www.wesleylowe.com, 10 June 2016.

Nagin, Daniel (1978), "Crime Rates, Sanction Levels, and Constraints on Prison Population," Law and Society Review, 12: 341-66.

Peretz, Don (1988), The Middle East Today (New York: Praeger).

Philips, L. and Votey, H. (1975), "Crime Control in California," Journal of Legal Studies, 4: 327-49. 
Pratt, John (1990), "Crime, Time, Youth and Punishment," Contemporary Crises, 14: 219-42.

Qardhawi, Yusuf (2003), Membumikan Syariat Islam, (Bandung: Mizan Pustaka).

Quinney, Richard (1970), The Social Reality of Crime, (Boston: Little, Brown).

Reiman, Jeffrey (1985), "Justice, Civilization, and the Death Penalty: Answering van den Haag," Philosophy and Public Affairs, 14: 115-48.

Sabiq, Sayyid (1980), Figh al-Sunnah, (Beirut: Dar al-Fikr).

Said, Abdul-Aziz (1979), "Precept and Practice of Human Rights in Islam," Universal Human Rights, 1: 63-79.

Schact, Joseph (1964), An Introduction to Islamic Law (New York: Clarendom Press).
SJ., Fadil (2008), Pasang Surut Peradaban Islam dalam Lintasan Sejarah. Cet. I, (Malang: UIN Malang Press).

Soenarjo, dkk. (2013), Al-Qur'an dan Terjemahnya, (Jakarta: Departemen Agama Republik Indonesia).

Syaltut, Mahmud (1996), Al-Islam, 'Aqidah wal Syari'ah, (Kairo: Dar al-Qalam).

United Nations Office on Drugs and Crime (UNDDC) (2014), Global Study on Homocide, April 2014.

Wikipedia, the free Encyclopedia (2007), List of Countries by Homicide Rate, Internet Resources, accessed through http://en.wikipedia.org. Accessed 10 June 2016.

Zuhaily, Wahbah, (1989), Al-Figh al-Islami wa Adillatuhu, (Damaskus: Dar Al-Fiqr). 